\title{
THE
}

\section{Nicoya Peninsula, Costa Rica: A single suite of Caribbean oceanic plateau magmas}

Christopher W. Sinton

University of Rhode Island

Robert A. Duncan

Percy Denyer

Follow this and additional works at: https://digitalcommons.uri.edu/gsofacpubs

Terms of Use

All rights reserved under copyright.

\section{Citation/Publisher Attribution}

Sinton, C. W., R. A. Duncan, and P. Denyer (1997), Nicoya Peninsula, Costa Rica: A single suite of Caribbean oceanic plateau magmas, J. Geophys. Res., 102(B7), 15507-15520, doi: 10.1029/97JB00681. Available at: https://doi.org/10.1029/97JB00681

This Article is brought to you for free and open access by the Graduate School of Oceanography at DigitalCommons@URI. It has been accepted for inclusion in Graduate School of Oceanography Faculty Publications by an authorized administrator of DigitalCommons@URI. For more information, please contact digitalcommons-group@uri.edu. 


\title{
Nicoya Peninsula, Costa Rica: A single suite of Caribbean oceanic plateau magmas
}

\author{
Christopher W. Sinton ${ }^{1}$ and Robert A. Duncan \\ College of Oceanic and Atmospheric Sciences, Oregon State University, Corvallis \\ Percy Denyer \\ Escuela Centroamericana de Geología, Universidad de Costa Rica, San Jose, Costa Rica
}

\begin{abstract}
The pre-Tertiary oceanic crust exposed on the west coast of Costa Rica has been broadly referred to as the Nicoya Complex. This study was designed to determine the age of the Nicoya Complex in the Nicoya Peninsula, Playa Jacó, and the Quepos Peninsula using ${ }^{40} \mathrm{Ar}-{ }^{39} \mathrm{Ar}$ radiometric dating and to assess the petrologic relationships between the different localities using major element, trace element, and $\mathrm{Sr}, \mathrm{Nd}, \mathrm{Pb}$ isotopic data. Radiometric ages of basalts and diabases from the Nicoya Peninsula are 88-90 Ma (with a weighted mean of $88.5 \mathrm{Ma}$ ), and those of two intrusive rocks (a gabbro and plagiogranite) are both 83-84 Ma. The combined geochemical data indicate that the sampled Nicoya Peninsula rocks belong to a single suite related by fractional crystallization of similar parental magmas. $\mathrm{Nd}$ and $\mathrm{Pb}$ isotopic ratios indicate a common mantle source distinct from that of mid-ocean ridge basalts. Both the age and composition of the Nicoya rocks are consistent with the idea that they are a part of the Caribbean Cretaceous oceanic plateau [Donnelly, 1994]. The Jacó lavas are geochemically similar to the Nicoya Peninsula suite, and a single age of $84 \mathrm{Ma}$ is identical to the age of the Nicoya Peninsula intrusives. The one analyzed Quepos basalt has a radiometric age of $\sim 64 \mathrm{Ma}$, and it is enriched in incompatible elements relative to the Nicoya rocks. Similarities in $\mathrm{Nd}$ and $\mathrm{Pb}$ isotopic ratios indicate that the Quepos and Nicoya/Jacó lavas were derived from a similar mantle source to that which produced the Nicoya rocks, possibly the Galapagos plume.
\end{abstract}

\section{Introduction}

Obducted oceanic crust exposed on the west coast of Costa Rica is broadly referred to as the Nicoya Complex [Dengo, 1962] (Figure 1). These rocks are composed of intermingled basalts (massive and pillowed flows, dikes, and breccias), gabbros and plagiogranites with interspersed pieces of radiolarian chert [e.g., Kuijpers, 1980; Alvarado et al., 1993; Denyer and Arias, 1993]. Outcrops are generally limited to coastal peninsulas with the most extensive exposures on the Nicoya Peninsula. The full extent of the obducted crust is not precisely known, but it is possible that the Nicoya Complex is part of a belt of accreted Mesozoic oceanic crust that extends southeastward through Panama into western Colombia and Ecuador [e.g., Escalante, 1990].

On the basis of the fossil ages of the radiolarian chert associated with the igneous rocks, most previous workers have divided the oceanic igneous rocks of the Nicoya Peninsula into an upper and a lower unit [Schmidt-Effing, 1979; Kuijpers, 1980; Bourgois et al., 1984; Gursky et al., 1984; Wildberg, 1984; Frisch et al., 1992]. The lower unit

\footnotetext{
${ }^{1}$ Now at Graduate School of Oceanography, University of Rhode Island, Narragansett.

Copyright 1997 by the American Geophysical Union.

Paper number 97JB00681.

0148-0227/97/97JB-00681\$09.00
}

was described as normal oceanic crust of Jurassic to Early Cretaceous age, and the upper unit was subdivided, based on composition, into a suite of Late Cretaceous oceanic rocks associated with the Caribbean oceanic plateau and a primitive arc series. However, our re-examination of contacts between chert and basalt demonstrated only intrusive (basalt into sediment) rather than depositional (sediment on basalt) relationships, so the sediment age cannot be used to constrain the basalt age. The division of the igneous rocks into two series of different ages is therefore open to question.

The Caribbean oceanic plateau (also called the Caribbean Cretaceous Basalt Province by Donnelly et al. [1990]) is composed of the thick oceanic crust that makes up the core of the Caribbean plate and numerous pieces of obducted oceanic crust along the plate margin [Donnelly et al. , 1990]. Debatable aspects of the Caribbean plateau include its formation location (Pacific or in situ) and the plate tectonic setting of origin (i.e., intraplate, ridge centered, back arc). The preexisting oceanic lithosphere which, based on seismic reflection profiles [Diebold et al., 1981] and plate reconstructions [Duncan and Hargraves, 1984], purportedly lies beneath the plateau has not yet been definitively identified in any of the on-land exposures nor has it been sampled by deep sea drilling. The exposed oceanic crust in western Costa Rica may play a very important role in understanding the nature of the plateau if, indeed, some part of the Nicoya Complex represents this preexisting oceanic crust. This possibility can be evaluated by determining the age and composition of the lavas. 


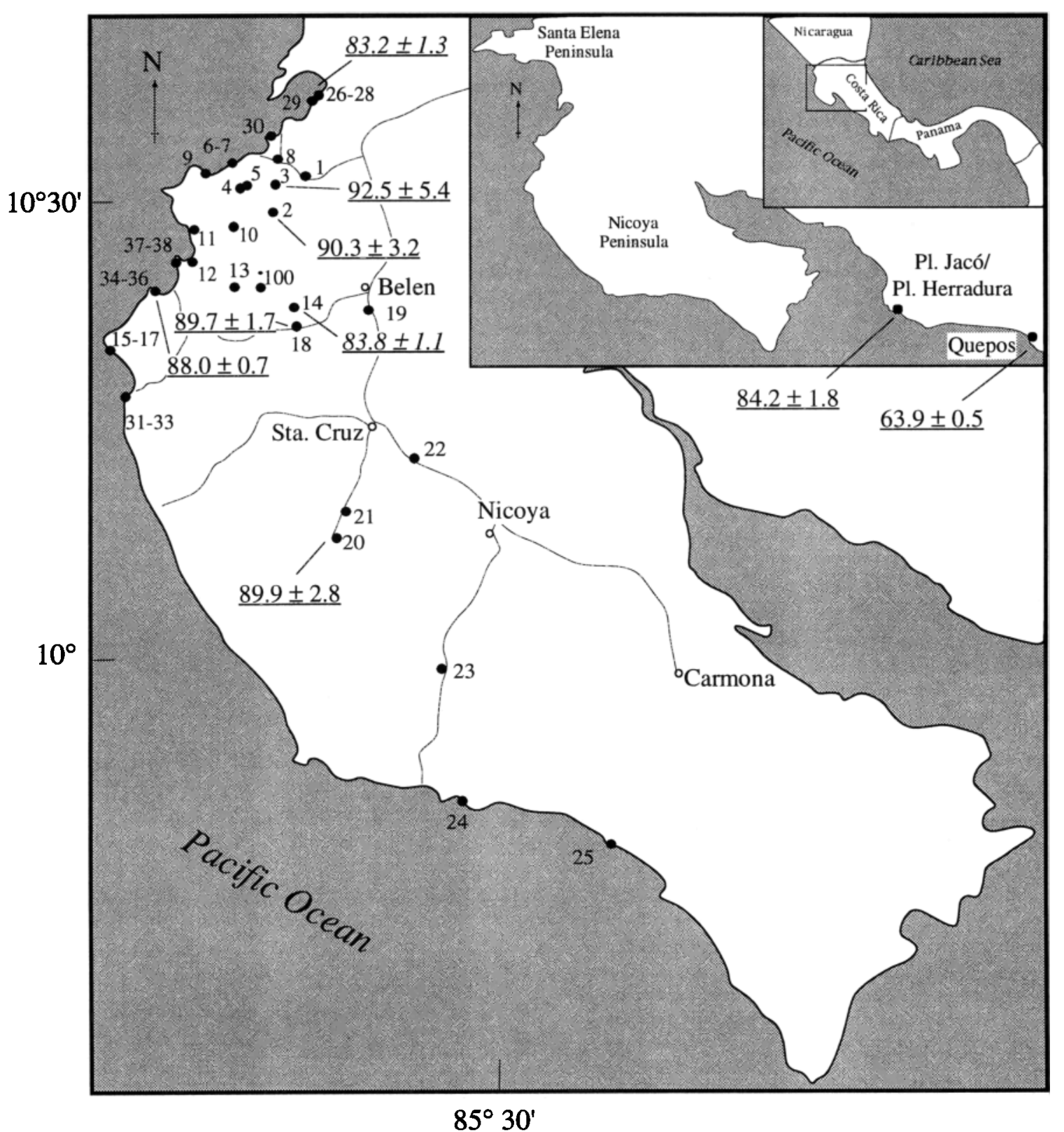

Figure 1. Schematic map of the Nicoya Peninsula with inset showing location of Playa Jacó and Quepos. Solid circles are sample locations. The ${ }^{40} \mathrm{Ar}-{ }^{39} \mathrm{Ar}$ plateau ages of basalts and diabases are given, with the ages of the intrusive rocks in italics. Thin lines on the Nicoya Peninsula are major roads.

This project was designed to (1) determine the radiometric age of rocks from the Nicoya Complex, (2) test the idea of an upper and lower series within the Nicoya Peninsula using ${ }^{40} \mathrm{Ar}-{ }^{39} \mathrm{Ar}$ dating and geochemistry, and (3) better constrain the origin of the Nicoya rocks with an improved geochemical data set. In addition, some samples were collected from coastal exposures of oceanic basalts at Playa Jacó and the Quepos Peninsula for comparison to the Nicoya rocks. We report ${ }^{40} \mathrm{Ar}-{ }^{39} \mathrm{Ar}$ radiometric ages as well as major element, trace element, and $\mathrm{Sr}, \mathrm{Nd}$, and $\mathrm{Pb}$ isotopic data from these three localities. Our data show that rocks from the Nicoya Peninsula erupted at $88-90 \mathrm{Ma}$, which is contemporaneous with other on-land Caribbean plateau sites in Haiti, Curaçao, and western Colombia [Sinton, 1996]. The geochemical data, in conjunction with previously published data, show that all of the rocks collected from the Nicoya Peninsula come from a similar mantle source and that all can be related by fractional crystallization of similar parental melts. $\mathrm{Nd}$ and $\mathrm{Pb}$ isotopic ratios from the Nicoya Peninsula, Playa Jacó, and Quepos are similar but are distinct from normal mid-ocean ridge basalts erupted on the East Pacific Rise. Altogether, these data do not support the division of the Nicoya Peninsula igneous rocks into two or more suites; rather, the rocks appear to be genetically related and are part of the Caribbean oceanic plateau.

\section{Previous Work}

Donnelly [1994] summarized the previous studies of the Nicoya Complex and the reader is referred to his paper for a more thorough description of these. The majority of the exposures of igneous oceanic rocks and oceanic sediments are 
on the Nicoya Peninsula, and smaller exposures are found along the coast to the north, at the Santa Elena Peninsula, and to the south, at Playa Jaco/Playa Herradura, and the Quepos Peninsula (Figure 1). For clarity, the rocks will be referred to by their locality, so the term Nicoya in this paper will refer to the Nicoya Peninsula (samples designated NC in Table 1).

In general, previous authors have subdivided the Nicoya Peninsula igneous rocks into two general units, termed the Matapalo and Esperanza units by Kuijpers [1980] and Bourgois et al. [1984]. This division was originally based on fossil age and field observations [Schmidt-Effing, 1979; Baumgartner et al., 1984], although no contact between the two units was defined [Kuijpers, 1980]. Later studies by Wildberg [1984] and Gursky et al. [1984] referred to these two units as the Lower and Upper Nicoya, with the units separated by a discontinuous layer of radiolarian chert. However, there are no observed depositional contacts between the radiolarian chert and the igneous rocks. This observation as well as considerable differences in the interpretation of the stratigraphy and origin of the rocks led Donnelly [1994] to suggest that the Nicoya Peninsula igneous rocks may be a single unit.

Previous radiometric ages of the Nicoya Peninsula rocks have not been useful in constraining their magmatic history. Alvarado et al. [1993] compiled K-Ar ages that range from 30 to $73 \mathrm{Ma}$, reflecting the effects of alteration and $40 \mathrm{Ar}$ loss and not the actual time span of volcanism. There have been several reports of fossil ages from the radiolarian chert assemblages that occur as inclusions within the igneous rocks throughout the peninsula. These assemblages have been assigned ages of Early Jurassic (Callovian) to Late Cretaceous (early Santonian) [Galli-Olivier, 1979; Bourgois et al., 1984; Baumgartner et al., 1984]. However, because of the intrusive relationships of the igneous rocks into the radiolarian chert, the fossil ages provide only a maximum crystallization age of the igneous rocks. The late Campanian ( 75-70 Ma,
[Gradstein et al., 1994]) Sabana Grande sediments conformably overlie the igneous rocks [Bourgois et al., 1984], placing a minimum age on eruption and crystallization of the magmas. This formation is a deep water assemblage of a sedimentary basalt/radiolarian chert breccia base overlain by thin siliceous mudstones grading into limestone [Bourgois et al., 1984].

There are no reported radiometric or fossil ages for the Playa Jac6/Herradura rocks. The basalts at Quepos are interbedded with Paleocene foraminifera and are overlain by early Eocene sediments [Schmidt-Effing, 1979; Baumgartner et al., 1984], somewhat older than the K-Ar reported age of 46.2 $\pm 4.4 \mathrm{Ma}$ [Alvarado et al., 1992 and references therein].

\section{Sample Descriptions and Mineralogy}

Rock samples were collected from the Nicoya Peninsula, Playa Jaco, and Quepos in March 1993. Sample locations are shown in Figure 1, and brief descriptions are given in Table 1. Sampling was concentrated in the northern Nicoya Peninsula because the goal was to identify and characterize the proposed older normal oceanic crust in this area. The best exposures are along the coast and road cuts. However, even in large exposures, bedding or paleohorizontal direction is impossible to determine owing to faulting, surficial weathering, and the often limited outcrop area. Some outcrops show spheroidally weathered rocks in which well-preserved, rounded clasts of diabase are found in a matrix of heavily weathered and friable material. Pillow structures are rarely observed in the northwestern peninsula.

Fractured, massive basalt flows exposed at the northern and southern ends of Playa Jacó were also sampled as well as at a road cut on the coast road just south of Playa Jacó (Table 1). All the basalts examined along the coast at Quepos are heavily altered and only three samples with the least apparent

Table 1. Costa Rica Sample Descriptions

\begin{tabular}{|c|c|c|c|}
\hline Sample & Location Description & Rock Type & Condition \\
\hline NC93-2 & massive basalt in Río Brasil, Pilas & $\begin{array}{l}\text { medium grain } \\
\text { basalt }\end{array}$ & $\begin{array}{l}\text { slight alteration, moderate alteration } \\
\text { near veins }\end{array}$ \\
\hline $\mathrm{NC93-3}$ & exposed hill near roadside, $2 \mathrm{~km}$ west of Sardinal & $\begin{array}{l}\text { medium-fine } \\
\text { grain basalt }\end{array}$ & $\begin{array}{l}\text { slight alteration, plagioclase } 0-10 \% \\
\text { replaced by clays }\end{array}$ \\
\hline NC93-11 & $\begin{array}{l}\text { small road cut across from entrance to Hotel Playa } \\
\text { Azucar, spheroidal blocks }\end{array}$ & $\begin{array}{l}\text { medium grain } \\
\text { basalt }\end{array}$ & $\begin{array}{l}\text { slight alteration, plagioclase } 10 \% \\
\text { replaced by clays }\end{array}$ \\
\hline NC93.13 & road cut $3 \mathrm{~km}$ north of Tempate & diabase & $\begin{array}{l}\text { slight alteration, some plagioclase cores } \\
\text { beginning to alter to clays }\end{array}$ \\
\hline NC93-14 & $\begin{array}{l}\text { north of El Edén, follow Quebrada Salto to hill where rock } \\
\text { exposed, great variation in grain size over short distance, } \\
\text { with contact unknown }\end{array}$ & gabbro & $\begin{array}{l}\text { altered, plagioclase partially replaced by } \\
\text { clays, some primary twinning seen, } \\
\text { graphic quartz and plagioclase }\end{array}$ \\
\hline NC93-18 & $\begin{array}{l}\text { quarry } 2 \mathrm{~km} \text { west of Coyolito, overlain by radiolarite, contact } \\
\text { inaccessible }\end{array}$ & $\begin{array}{l}\text { medium grain } \\
\text { basalt }\end{array}$ & light alteration, some quartz veins \\
\hline NC93-20 & road cut at top of Vista al Mar & fine grain basalt & light to moderate alteration \\
\hline NC93-34 & $\begin{array}{l}\text { north side of Punta Sabana, flat-lying and cliff-exposed } \\
\text { basalt/diabase and radiolarite, basalt is massive,with igneous } \\
\text { and fault contact w/ radiolarite, primary bedding of } \\
\text { radiolarite (red and gray/white) preserved, cut by dikes }\end{array}$ & diabase & $\begin{array}{l}\text { light alteration, plagioclase } 0-25 \% \\
\text { replaced by clays, depending on } \\
\text { proximity to veins }\end{array}$ \\
\hline NC93-26 & $\begin{array}{l}\text { Coastal exposure, south of Pl.aya Monte del Barco (north of } \\
\text { Playa Panama) }\end{array}$ & plagiogranite & $\begin{array}{l}\text { altered, plagioclase partially replaced by } \\
\text { albite + clay, pyroxene with fractured } \\
\text { texture altering to secondary oxides }\end{array}$ \\
\hline JC93-1 & $\begin{array}{l}\text { road cut } 1.2 \mathrm{~km} \text { south of last entrance to Playa Jaco, massive, } \\
\text { fractured basalt, no sediments, } 20 \mathrm{~m} \text { high }\end{array}$ & $\begin{array}{l}\text { medium grain } \\
\text { basalt }\end{array}$ & variably altered \\
\hline JC93-3 & $\begin{array}{l}\text { north end of Playa Jacó Basalt crops out on cliffs and flat } \\
\text { lying on beach, similar to } S \text { end }\end{array}$ & $\begin{array}{l}\text { medium grain } \\
\text { basalt }\end{array}$ & variably altered, heavy vein penetration \\
\hline QP93-1 & $\begin{array}{l}\text { south end of beach } 1 \text { at Quepos, basalt in cliff and large } \\
\text { "islands" on beach, massive with columnar joints, some } \\
\text { alteration and veins }\end{array}$ & fine grain basalt & $\begin{array}{l}\text { light to moderate alteration, some fresh } \\
\text { but partially resorbed plagioclase } \\
\text { phenocrysts }\end{array}$ \\
\hline
\end{tabular}


alteration were taken from the beach just north of the entrance to Manuel Antonio National Park (Table 1).

Thin sections were made of all of the samples in order to determine their mineralogy and suitability for geochemical and geochronological analyses. The rocks were divided into five categories based on petrographic observations: basalt, basaltic breccia, diabase, gabbro, and plagiogranite. Basaltic samples are fine grained and generally aphyric and consist of plagioclase, pyroxene, Fe-Ti oxides, and altered mesostasis. Only one basaltic breccia was collected (NC93-25), and it is composed of a heavily altered matrix surrounding basalt clasts. Diabasic samples have the same mineralogy as the basalts except that they are holocrystalline, are coarser grained, and have trace amounts of tabular apatite. Spheroidally weathered samples are usually diabasic in texture. Isotropic gabbroic samples have the same mineralogy as the basalts and diabases but have grain sizes up to $10 \mathrm{~mm}$. The plagiogranites all have coarse textures and are composed of myrmeketic plagioclase and quartz with lesser amounts of green clinopyroxene (hedenbergite) and $\mathrm{Fe}-\mathrm{Ti}$ oxides. A cumulate gabbro (NC93-100) contains large $(\sim 4 \mathrm{~cm}$ diameter) unzoned plagioclase $\left(\mathrm{An}_{85-86}\right)$, clinopyroxene $\left(E n_{51}\right)$ [Sinton, 1996], and trace olivine (completely replaced by iddingsite) set in a diabasic matrix of plagioclase, clinopyroxene, and Fe-Ti oxides.

The rocks show varying degrees of alteration with most samples having relatively pristine pyroxene and relatively fresh to partially altered plagioclase (to colorless clays). In the basalts, the mesostasis has altered to chlorite and finegrained secondary oxides. Thin veins of prehnite and rare calcite are found in most of the samples, and the density of veins generally correlates with the degree of alteration. The plagiogranites are all moderately to heavily altered.

\section{Results}

\section{Geochronology}

Age determinations for whole rock and plagioclase separates from the least altered samples were performed at Oregon State University (OSU) using standard ${ }^{40} \mathrm{Ar}-{ }^{39} \mathrm{Ar}$ incremental heating techniques [Duncan and Hargraves, 1990; Duncan and Hogan , 1994]. Whole rock samples were either crushed in bulk in a ceramic jaw crusher and sieved to a uniform $0.5-1 \mathrm{~mm}$ grain size or cut into mini cores. Plagioclase crystals were magnetically separated from diabase, gabbro, and plagiogranite samples, checked for purity under a binocular microscope, and washed for $30 \mathrm{~s}$ in 5\% hydrofluoric acid. All samples were ultrasonically cleaned in distilled water. Samples were sealed in evacuated quartz glass vials and irradiated for 6 hours at the OSU TRIGA nuclear reactor facility. Neutron flux during irradiation was monitored by FCT-3 biotite (27.7 Ma, [Hurford and Hammerschmidt, 1985]). Ar isotopic compositions of the crushed whole rock samples and some of the plagioclase separates $(\sim 500 \mathrm{mg})$ were determined using an Associated Electrical Industries (AEI) MS-10S mass spectrometer. The mini cores and the other plagioclase separates $(\sim 100 \mathrm{mg})$ were analyzed using a Mass Analyzer Products (MAP) mass spectrometer, equipped with a low-blank, double-vacuum resistance furnace.

Individual ages for each of the ${ }^{40} \mathrm{Ar}-{ }^{39} \mathrm{Ar}$ temperature steps were calculated after corrections for background, mass fractionation, isotopic interferences, and atmospheric argon contamination $\left({ }^{40} \mathrm{Ar} /{ }^{36} \mathrm{Ar}=295.5\right)$. From the heating steps, age spectrum diagrams (age versus $\%{ }^{39} \mathrm{Ar}$ released) were generated (Figure 2). Plateau ages were calculated from consecutive steps that are concordant within $1 \sigma$ error using the procedure described by Dalrymple et al. [1988], in which step ages were weighted by the inverse of their variance (Table 2). Isotope correlation diagrams $\left({ }^{36} \mathrm{Ar} /{ }^{40} \mathrm{Ar}\right.$ versus $\left.{ }^{39} \mathrm{Ar} /{ }^{40} \mathrm{Ar}\right)$ were also made for each analysis, in which the slope is proportional to the age (isochron) and the inverse of the $y$ intercept gives the initial ${ }^{40} \mathrm{Ar} /{ }^{36} \mathrm{Ar}$ composition. The isochron ages are calculated using the same heating steps as in the plateau ages.

We define a reliable crystallization age based on the criteria of Pringle [1993] as follows: (1) a well-defined age spectrum plateau of at least three concordant consecutive steps that represents at least of $50 \%$ of the total ${ }^{39} \mathrm{Ar}$ released; (2) an isochron age concordant with the plateau age and with a value for the $\chi^{2}$-statistic SUMS/N-2 [York, 1969] below the 95\% confidence level; and (3) a ${ }^{40} \mathrm{Ar} /{ }^{36} \mathrm{Ar}$ intercept that is statistically indistinguishable from the atmospheric value 295.5.

The SUMS/N-2 cutoff values are taken from Pringle [1993, Table 2]. For three-, four-, and five-point isochrons, the cutoff values are $3.84,3.00$, and 2.60 , respectively.

Many of the samples from the Nicoya Peninsula displayed erratic step ages, from which no age plateaus or isochrons could be discerned. This can be attributed to a combination of alteration effects, ${ }^{37} \mathrm{Ar}$ and ${ }^{39} \mathrm{Ar}$ recoil, and the low $\mathrm{K}_{2} \mathrm{O}$ contents of the rocks. Some of the plagioclase separates (NC93-36 and NC93-9) gave step ages that increased with increasing temperature, up to $180 \mathrm{Ma}$. Evidently they contained some component of excess radiogenic ${ }^{40} \mathrm{Ar}$ of which even small amounts can produce erroneous ages, given the low $\mathrm{K}_{2} \mathrm{O}$ content $(<0.10 \%)$ of these rocks. Plagioclase separates from all but one of the analyzed plagiogranite samples gave nonconcordant step ages that were usually less than $80 \mathrm{Ma}$. In this section, we report only the results from the samples that yielded reliable crystallization ages (Table 2).

Of 13 analyzed samples from the Nicoya Peninsula, 7 gave reliable crystallization ages (Figure 2). Five (four basalts and one diabase) gave plateau ages ranging from 88.0 to $92.5 \mathrm{Ma}$ (a weighted mean of the ages is $88.5 \mathrm{Ma}$ and a nonweighted mean is $90.1 \mathrm{Ma}$ ). Of particular interest is the diabase NC9334 (Punta Sabana), which was taken near a large inclusion (50 $\mathrm{m}$ ) of radiolarian chert. The plateau age of $88.0 \pm 0.7 \mathrm{Ma}$ indicates the age of intrusion and confirms that magmatism occurred well after the Jurassic-Early Cretaceous radiolarian chert. Plagioclase separated from a gabbro (NC93-14B) and a plagiogranite (NC93-26) gave statistically indistinguishable plateau ages of $83.8 \pm 1.1 \mathrm{Ma}$ and $83.2 \pm 1.3 \mathrm{Ma}$, respectively. The significantly lower ages of the intrusive rocks relative to the analyzed basalts and diabase indicate that some magmatic activity occurred at least 5-7 m.y. after initial basalt eruptions at 88-90 Ma.

One of two analyzed basalts from Jacó (JC93-1) yielded a reliable crystallization age with a three-step plateau of $84.2 \pm$ $1.8 \mathrm{Ma}$, an isochron of $83.4 \pm 2.5 \mathrm{Ma}$, and an initial ${ }^{40} \mathrm{Ar} /{ }^{36} \mathrm{Ar}$ ratio of $295.6 \pm 6.9$ (Figure 2). The lower initial step age indicates some radiogenic ${ }^{40} \mathrm{Ar}$ loss from less retentive (alteration) sites. The consistent plateau and isochron ages of this sample indicate a volcanic event younger than the eruption of the Nicoya Peninsula basalts but perhaps related to the intrusions. 

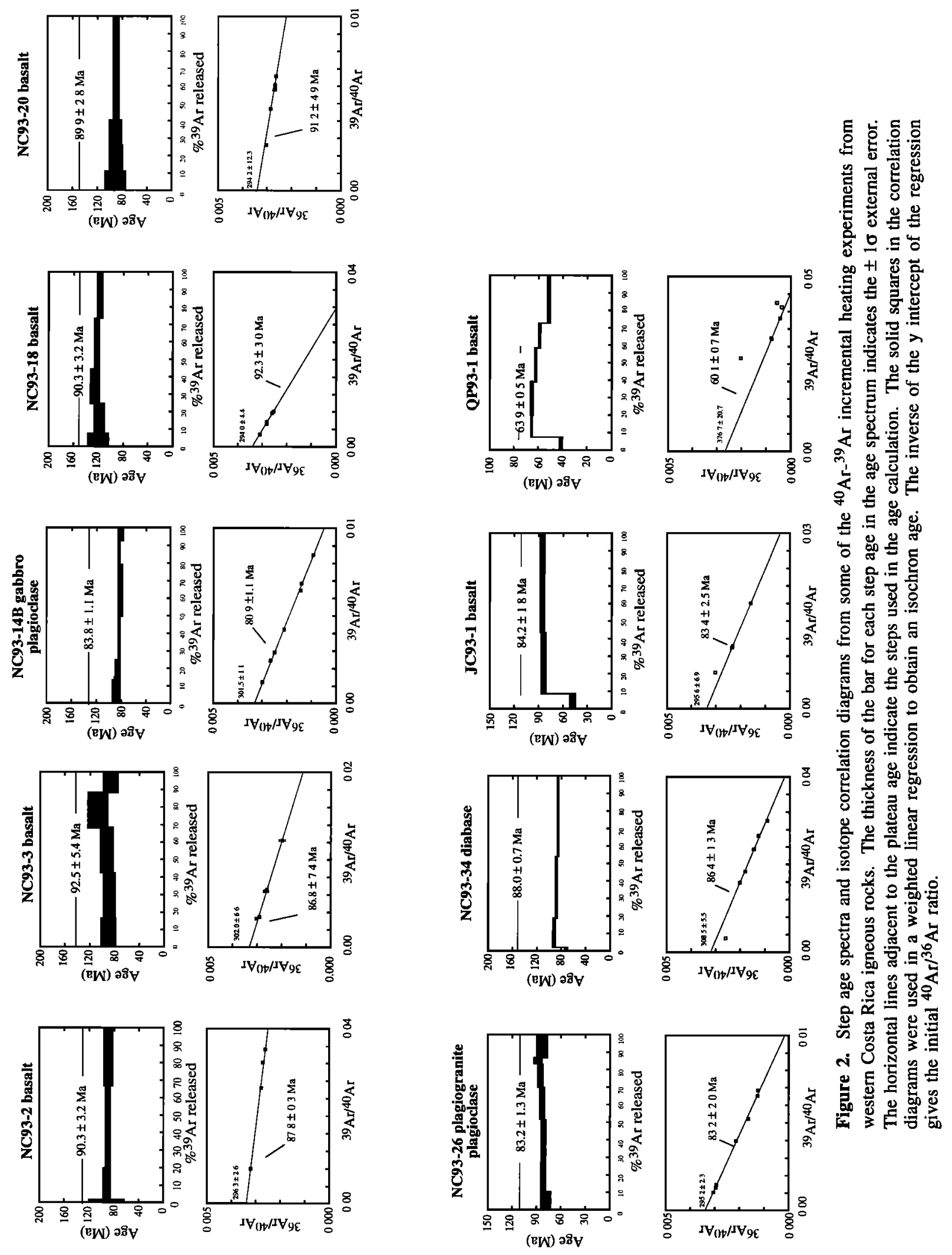
Table 2. The ${ }^{40} \mathrm{Ar}-{ }^{39} \mathrm{Ar}$ Plateau and Isochron Ages for Basaltic Rocks From the Nicoya Complex, Costa Rica

\begin{tabular}{|c|c|c|c|c|c|c|c|}
\hline Sample & Material & $\begin{array}{l}\text { Plateau Age } \\
\text { by } 1 / \sigma^{2}, \text { m.y }\end{array}$ & $\begin{array}{l}{ }^{39} \mathrm{Ar} \text { Percent } \\
\text { of Total }\end{array}$ & Isochron Age, m.y. & $\mathbf{N}$ & $\begin{array}{c}{ }^{40} \mathrm{Ar} /{ }^{36} \mathrm{Ar} \text { Intercept } \pm \\
1 \sigma\end{array}$ & $\frac{\text { SUMS }}{N-2}$ \\
\hline $\begin{array}{l}\text { NC93-2 } \\
\text { NC93-3 } \\
\text { NC93-18 } \\
\text { NC93-20 } \\
\text { NC93-34 }\end{array}$ & $\begin{array}{l}\text { whole rock } \\
\text { whole rock } \\
\text { whole rock } \\
\text { whole rock } \\
\text { whole rock }\end{array}$ & $\begin{array}{l}90.3 \pm 3.2 \\
92.5 \pm 5.4 \\
89.7 \pm 1.7 \\
89.9 \pm 2.8 \\
88.0 \pm 0.7\end{array}$ & $\begin{array}{l}\text { Nicoya Peni } \\
100 \\
100 \\
100 \\
100 \\
97\end{array}$ & $\begin{array}{c}\text { la Basalt and Diabase } \\
87.8 \pm 0.3 \\
86.8 \pm 7.4 \\
92.3 \pm 3.0 \\
85.9 \pm 3.3 \\
86.4 \pm 1.3\end{array}$ & $\begin{array}{l}4 \\
5 \\
5 \\
5 \\
5\end{array}$ & $\begin{array}{l}296.3 \pm 2.6 \\
302.0 \pm 6.6 \\
294.0 \pm 4.4 \\
299.7 \pm 6.7 \\
308.1 \pm 5.5\end{array}$ & $\begin{array}{l}1.00 \\
0.52 \\
0.47 \\
0.16 \\
0.29\end{array}$ \\
\hline $\begin{array}{l}\text { NC93-14B } \\
\text { NC93-26 }\end{array}$ & $\begin{array}{l}\text { plagioclase } \\
\text { plagioclase }\end{array}$ & $\begin{array}{l}83.8 \pm 1.1 \\
83.2 \pm 1.3\end{array}$ & $\begin{array}{l}\text { Nicoya } \\
100^{\text {N }} \\
100\end{array}$ & $\begin{array}{r}\text { insula Intrusives } \\
80.9 \pm 1.1 \\
83.2 \pm 2.0\end{array}$ & $\begin{array}{l}7 \\
7\end{array}$ & $\begin{array}{l}301.5 \pm 1.1 \\
295.2 \pm 2.3\end{array}$ & $\begin{array}{l}2.00 \\
2.20\end{array}$ \\
\hline JC93-1* & whole rock & $84.2 \pm 1.8$ & 92 & $83.4 \pm 2.5$ & 3 & $295.6 \pm 6.9$ & 0.08 \\
\hline QP93-1 ${ }^{\dagger}$ & whole rock & $63.9 \pm 0.5$ & 51 & $60.1 \pm 0.7$ & 3 & $376.7 \pm 20.7$ & 0.08 \\
\hline
\end{tabular}

Ages were calculated using the following decay constants: $\lambda_{\mathrm{e}}=0.581 \times 10^{-10} \mathrm{yr}^{-1}, \lambda_{\beta}=4.963 \times 10^{-10} \mathrm{yr}^{-1}$. Isotopic interferences for the Oregon State University TRIGA reactor are $\left({ }^{36} \mathrm{Ar} /{ }^{37} \mathrm{Ar}\right)_{\mathrm{Ca}}=2.64 \times 10^{-4},\left({ }^{39} \mathrm{Ar} /{ }^{37} \mathrm{Ar}\right)_{\mathrm{Ca}}=6.73 \times 10^{-4}$, and $\left({ }^{40} \mathrm{Ar} /{ }^{39} \mathrm{Ar}\right)_{\mathrm{K}}=1.00 \times 10^{-3}$. Errors for both step age plateaus and isochrons are reported to $2 \mathrm{~g}$. Ages are corrected for ${ }^{37} \mathrm{Ar}$ decay, half-life $=35.1$ days. $\mathrm{N}$ refers to the number of steps used in the isochron calcuation. SUMS/(N-2) is the $\chi^{2}$-statistic from York [1969].

*Sample from Playa Jacó.

†Sample from Quepos.

Only one Quepos sample (QP93-1) was considered suitable for analysis, although it is moderately altered and very fine grained. A three-step (of six) plateau gave an age of $63.9 \pm$ $0.5 \mathrm{Ma}$, although the isochron age derived from the same steps is slightly younger $(60.1 \pm 0.7 \mathrm{Ma})$ and the initial $\mathrm{Ar}$ isotopic composition is considerably higher than atmospheric (376.7) which is an artifact of fitting only three points (Figure 2). The younger ages of the higher temperature steps can be attributed to recoil of ${ }^{39} \mathrm{Ar}$ during irradiation, a problem often encountered with very fine grained samples. We consider the plateau age to be the best estimate of the time of crystallization of the Quepos basalts, and it is consistent with the Paleocene age of sediments intercalated with the basalts [Schmidt-Effing, 1979; Baumgartner et al., 1984].

\section{Mineral Chemistry}

Analyses of pyroxene and plagioclase are reported by Sinton [1996]. The trend of the pyroxenes is roughly similar to that of the Skaergaard intrusion clinopyroxenes [e.g., Deer et al. , 1992] and is consistent with the Nicoya Peninsula magmas being derived from fractional crystallization of tholeiitic parental melts.

\section{Major and Trace Element Geochemistry}

All the samples were analyzed for major elements and $\mathrm{Ni}$, $\mathrm{Cr}, \mathrm{Sc}, \mathrm{V}, \mathrm{Sr}$, and $\mathrm{Y}$ by $\mathrm{X}$ ray fluorescence $(\mathrm{XRF})$ at Washington State University using a Rigaku 3370 spectrometer [Hooper et al. , 1993]. A subset of the samples was analyzed for $\mathrm{Rb}, \mathrm{Y}, \mathrm{Zr}, \mathrm{Nb}, \mathrm{Ba}, \mathrm{Hf}, \mathrm{Ta}, \mathrm{Pb}, \mathrm{Th}, \mathrm{U}$, and the rare earth elements (REE) using a V.G. Plasmaquad inductively coupled plasma mass spectrometer (ICP-MS) at Oregon State University [Pyle et al. , 1995]. Samples were powdered for the XRF and some of the ICP-MS analyses using a tungsten carbide (WC) mill. For some of the ICP-MS analyses, cleaned rock chips were powdered in a ceramic mortar. There were no apparent differences between the ICP-MS results from sample duplicates using the two preparation methods, except the WC- powdered samples gave higher Ta values. Accordingly, Ta concentrations for WC-powdered samples are not reported. $\mathrm{Pb}$ concentrations were reliably measured in only some of the samples. ICP-MS analyses of the basalt standard W-1 agree with accepted values [Sinton, 1996].

Some of the major and trace element data are listed in Table 3 , and the complete dataset is reported by Sinton [1996]. The basalts, diabases, and gabbros from the Nicoya Peninsula and Jaco have tholeiitic compositions with $\mathrm{MgO}$ contents ranging from 10.7 to $4.0 \%$. The plagiogranites have andesitic to dioritic compositions $\left(52-69 \% \mathrm{SiO}_{2}\right)$. The two analyzed Quepos rocks are transitional to alkalic basalts.

Our major and trace element data and those from previous studies [Wildberg, 1984; Frisch et al., 1992] from the Nicoya Peninsula are plotted on several variation diagrams of $\mathrm{MgO}$ versus major elements and the relatively immobile trace elements (Figure 3). Elements that are affected by alteration and are present in low abundances, such as $\mathrm{K}$ and $\mathrm{Rb}$, show considerable scatter and are not plotted. These plots, in addition to illustrating the wide range in $\mathrm{MgO}$ content for the Nicoya rocks, demonstrate a single coherent trend for all samples. A first-order interpretation of this trend is that the rocks are derived from similar parent magmas by fractional crystallization. The Jacó rocks fall along the Nicoya trend while the Quepos basalts show distinctly different trends for some of the elements [Sinton, 1996].

The role of fractional crystallization in the evolution of the Nicoya Peninsula rocks can be assessed using the variation diagrams. The decreasing concentrations of certain elements or element ratios with decreasing $\mathrm{MgO}$ content reflect the crystallization and removal of particular minerals. All of the major element variation diagrams, with the exception of those for $\mathrm{FeO}$ and $\mathrm{TiO}_{2}$, show continuous, roughly linear trends. $\mathrm{FeO}$ and $\mathrm{TiO}_{2}$ both increase with decreasing $\mathrm{MgO}$ until $4 \%$ $\mathrm{MgO}$, at which point they decrease. This inflection is likely due to the appearance of Fe-Ti oxides on the liquidus. At greater $\mathrm{MgO}$ contents, there are no obvious inflections in the trend and therefore the fractionating mineral assemblage 
Table 3. Major and Trace Element Analyses for the Costa Rica Igneous Rocks

\begin{tabular}{|c|c|c|c|c|c|c|c|c|c|c|c|c|}
\hline & NC93-2 & NC93-3 & NC93-11 & NC93-13 & NC93-14B & NC93-18 & NC93-20 & NC93-26 & NC93-34 & JC93-1 & JC93-3 & QP93-1 \\
\hline $\begin{array}{l}\mathrm{SiO}_{2} \\
\mathrm{Al}_{2} \mathrm{O}_{3}\end{array}$ & $\begin{array}{l}50.18 \\
13.58\end{array}$ & $\begin{array}{l}50.50 \\
14.44\end{array}$ & $\begin{array}{l}50.05 \\
14.27\end{array}$ & $\begin{array}{l}50.47 \\
14.26\end{array}$ & $\begin{array}{l}51.43 \\
13.38\end{array}$ & $\begin{array}{l}50.83 \\
13.99\end{array}$ & $\begin{array}{r}50.6 \\
14.34\end{array}$ & $\begin{array}{l}63.62 \\
11.18\end{array}$ & $\begin{array}{l}51.19 \\
14.72\end{array}$ & $\begin{array}{l}51.38 \\
14.63\end{array}$ & $\begin{array}{l}49.57 \\
14.43\end{array}$ & $\begin{array}{l}49.44 \\
13.29\end{array}$ \\
\hline $\mathrm{TiO}_{2}$ & 1.68 & 1.04 & 1.00 & 1.26 & 1.87 & 1.03 & 0.98 & 1.02 & 1.01 & 1.13 & 1.23 & 2.94 \\
\hline $\mathrm{FeO}$ & 13.31 & 10.55 & 10.38 & 10.77 & 13.46 & 10.25 & 9.65 & 13.51 & 9.44 & 9.86 & 11.56 & 11.77 \\
\hline $\mathrm{MnO}$ & 0.23 & 0.21 & 0.18 & 0.19 & 0.21 & 0.19 & 0.19 & 0.16 & 0.20 & 0.18 & 0.22 & 0.19 \\
\hline $\mathrm{CaO}$ & 10.57 & 12.66 & 12.11 & 12.35 & 9.11 & 11.66 & 12.54 & 4.06 & 12.01 & 12.19 & 10.89 & 7.68 \\
\hline $\mathrm{MgO}$ & 6.59 & 8.82 & 8.93 & 8.26 & 5.51 & 8.82 & 8.73 & 0.39 & 8.55 & 8.79 & 8.68 & 7.33 \\
\hline $\mathrm{K}_{2} \mathrm{O}$ & 0.11 & 0.07 & 0.07 & 0.10 & 0.14 & 0.10 & 0.06 & 0.14 & 0.38 & 0.05 & 0.13 & 0.87 \\
\hline $\mathrm{Na}_{2} \mathrm{O}$ & 2.73 & 1.59 & 1.86 & 2.33 & 3.11 & 2.13 & 1.82 & 5.74 & 2.54 & 2.08 & 2.77 & 5.38 \\
\hline $\mathrm{P}_{2} \mathrm{O}_{5}$ & 0.13 & 0.07 & 0.07 & 0.09 & 0.14 & 0.07 & 0.07 & 0.29 & 0.07 & 0.08 & 0.09 & 0.27 \\
\hline L.O.I. & 1.56 & 3.31 & 3.29 & 2.11 & 4.42 & 3.59 & 3.89 & 1.20 & 2.90 & 3.26 & 3.64 & 2.83 \\
\hline Total & 100.67 & 103.26 & 102.20 & 102.19 & 102.79 & 102.66 & 102.87 & 101.31 & 103.01 & 103.62 & 103.21 & 102.00 \\
\hline $\mathrm{Ni}$ & 48 & 91 & 84 & 87 & 18 & 93 & 106 & 0 & 100 & 88 & 97 & 120 \\
\hline $\mathrm{Cr}$ & 70 & 288 & 200 & 242 & 8 & 284 & 209 & 1 & 296 & 311 & 202 & 269 \\
\hline Sc & 46 & 52 & 55 & 49 & 47 & 50 & 50 & 23 & 53 & 54 & 52 & 34 \\
\hline$v$ & 406 & 319 & 323 & 330 & 415 & 324 & 319 & 2 & 333 & 335 & 343 & 383 \\
\hline $\mathrm{Sr}$ & 140 & 171 & 100 & 146 & 298 & 218 & 178 & 83 & 139 & 87 & 76 & 275 \\
\hline $\mathbf{R b}$ & 1.10 & 0.54 & 0.42 & 1.31 & 2.17 & 0.47 & 0.80 & & 3.23 & 0.41 & 0.87 & 11.78 \\
\hline $\mathbf{Y}$ & 34 & 22 & 15 & 21 & 34 & 16 & 15 & & 17 & 18 & 21 & 36 \\
\hline $\mathrm{Zr}_{\mathbf{r}}$ & 107 & 58 & 31 & 43 & 69 & 49 & 44 & & 39 & 50 & 55 & 194 \\
\hline $\mathrm{Nb}$ & 5.8 & 3.4 & 3.0 & 4.3 & 7.2 & 3.3 & 3.0 & & 3.5 & 4.5 & 3.4 & 19.0 \\
\hline $\mathrm{Ba}$ & 20 & 10 & 11 & 66 & 41 & 31 & 7 & & 66 & 12 & 22 & 159 \\
\hline $\mathrm{La}$ & 3.99 & 2.31 & 1.98 & 3.20 & 5.16 & 2.16 & 2.15 & & 2.43 & 2.73 & 2.73 & 13.54 \\
\hline $\mathrm{Ce}$ & 11.43 & 6.89 & 5.40 & 8.50 & 13.73 & 5.87 & 5.59 & & 6.44 & 7.46 & 7.26 & 34.14 \\
\hline Pr & 1.93 & 1.13 & 0.91 & 1.43 & 2.24 & 0.96 & 0.91 & & 1.07 & 1.21 & 1.20 & 4.92 \\
\hline Nd & 9.99 & 5.83 & 4.52 & 7.13 & 11.42 & 4.95 & 4.76 & & 5.30 & 5.95 & 6.24 & 22.58 \\
\hline Sm & 3.39 & 1.92 & 1.55 & 2.33 & 3.68 & 1.69 & 1.60 & & 1.77 & 1.89 & 2.00 & 6.00 \\
\hline $\mathrm{Eu}$ & 1.20 & 0.72 & 0.59 & 0.87 & 1.34 & 0.65 & 0.61 & & 0.68 & 0.71 & 0.75 & 1.99 \\
\hline Gd & 4.19 & 2.65 & 2.16 & 3.19 & 4.59 & 2.26 & 2.15 & & 2.30 & 2.56 & 2.64 & 6.77 \\
\hline $\mathrm{Tb}$ & 0.89 & 0.51 & 0.41 & 0.60 & 0.95 & 0.46 & 0.43 & & 0.46 & 0.47 & 0.52 & 1.21 \\
\hline Dy & 5.35 & 3.27 & 2.65 & 3.71 & 5.64 & 2.79 & 2.62 & & 2.82 & 3.11 & 3.34 & 6.53 \\
\hline Ho & 1.22 & 0.75 & 0.59 & 0.82 & 1.19 & 0.62 & 0.56 & & 0.62 & 0.68 & 0.76 & 1.28 \\
\hline $\mathrm{Er}$ & 3.38 & 2.17 & 1.51 & 1.92 & 3.30 & 1.64 & 1.51 & & 1.56 & 1.77 & 2.01 & 2.96 \\
\hline $\mathrm{Tm}$ & 0.52 & 0.33 & 0.25 & 0.32 & 0.47 & 0.27 & 0.24 & & 0.26 & 0.30 & 0.34 & 0.48 \\
\hline $\mathrm{Yb}$ & 3.34 & 2.03 & 1.44 & 1.81 & 3.19 & 1.60 & 1.55 & & 1.54 & 1.72 & 2.06 & 2.62 \\
\hline Lu & 0.51 & 0.31 & 0.23 & 0.31 & 0.51 & 0.23 & 0.24 & & 0.26 & 0.29 & 0.32 & 0.41 \\
\hline Hf & 2.98 & 1.57 & 0.94 & 1.36 & 2.22 & 1.29 & 1.18 & & 1.14 & 1.29 & 1.52 & 4.62 \\
\hline $\mathrm{Ta}$ & & 0.23 & 0.18 & 0.29 & & 0.20 & 0.18 & & 0.23 & 0.30 & 0.23 & 1.24 \\
\hline $\mathrm{Pb}$ & & 0.32 & & & & & & & & & & \\
\hline Th & 0.38 & 0.27 & 0.11 & 0.18 & 0.31 & 0.14 & 0.16 & & 0.20 & 0.28 & 0.26 & 1.38 \\
\hline $\mathbf{U}$ & 0.11 & 0.04 & 0.03 & 0.04 & 0.09 & 0.05 & 0.06 & & 0.05 & 0.07 & 0.07 & 0.34 \\
\hline
\end{tabular}

Major elements and $\mathrm{Sc}, \mathrm{Cr}, \mathrm{Ni}, \mathrm{V}$, and $\mathrm{Sr}$ determined by $\mathrm{X}$ ray fluorescence; all other trace elements were determined by inductively coupled plasma mass spectrometry.

remained relatively constant. The fractionation of clinopyroxene is evident from the continuous decrease in $\mathrm{CaO}$, Sc, and $\mathrm{Cr}$ with decreasing $\mathrm{MgO}$. The decrease in $\mathrm{Al}_{2} \mathrm{O}_{3}$ and $\mathrm{Ni}$ can be attributed to the removal of plagioclase and olivine, respectively. Together, the variation diagrams are consistent with the removal of clinopyroxene, plagioclase, and olivine from $\sim 9 \% \mathrm{MgO}$ to $\sim 4 \% \mathrm{MgO}$, at which point $\mathrm{Fe}-\mathrm{Ti}$ oxides join the fractionating assemblage.

Petrographic observations are generally consistent with this interpretation. As previously stated, all samples (except
NC93-100) are aphyric, and petrographic observations are of limited help in determining the fractionating mineral assemblage. However, the cumulate gabbro NC93-100 contains large crystals of clinopyroxene $\left(\mathrm{En}_{51}\right)$, plagioclase $\left(A n_{85}\right)$ [Sinton, 1996], and what appear to be olivine pseudomorphs set in a basaltic matrix. This cumulate assemblage may represent the early crystallizing phases of the Nicoya suite.

The major and trace element data indicate that the Nicoya Peninsula plagiogranites were derived from the more primitive 


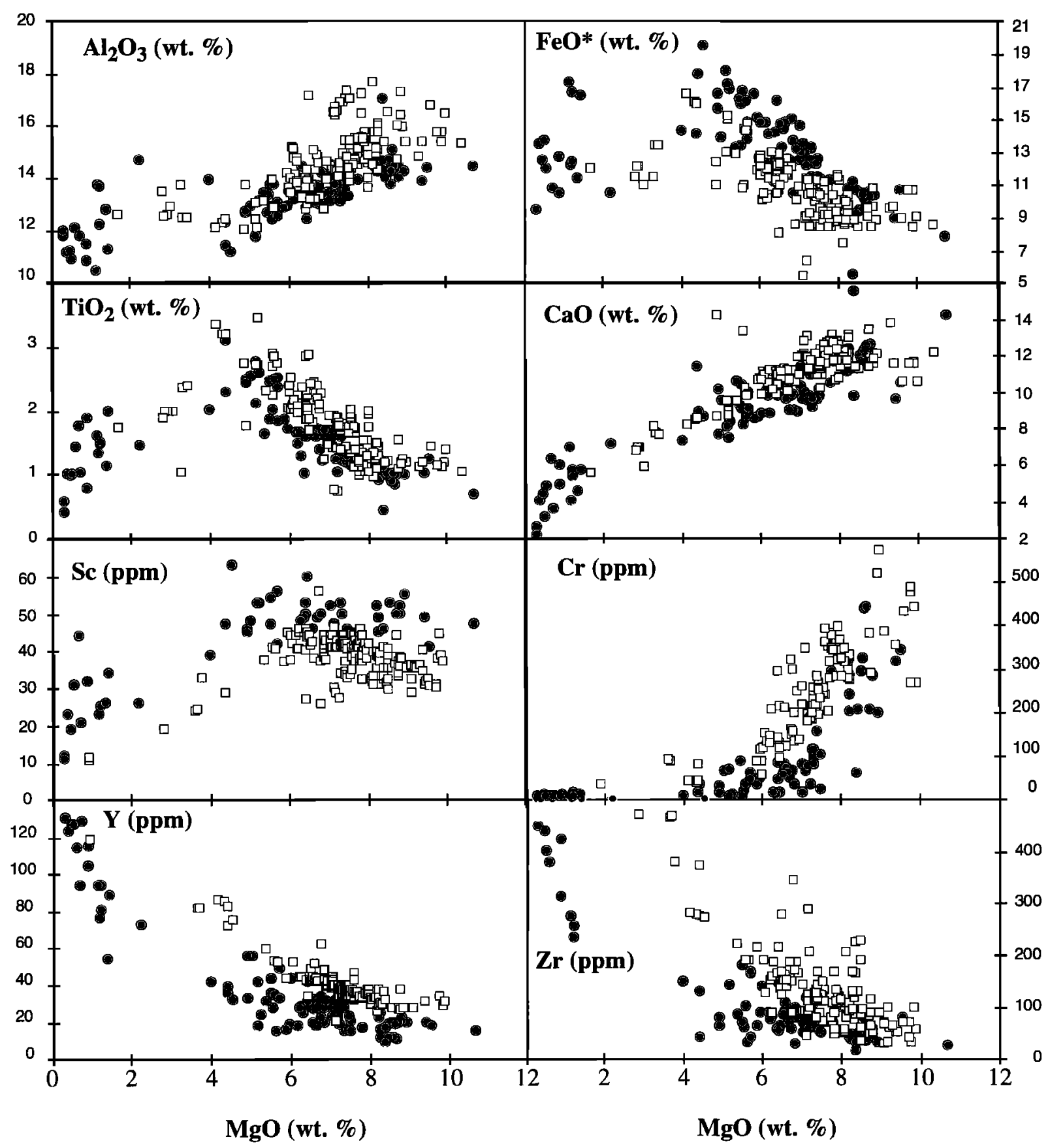

Figure 3. Variation diagrams of some major and trace elements versus $\mathrm{MgO}$ for the Nicoya Peninsula rocks (solid circles) using data compiled from this paper, Sinton [1996], Wildberg [1984], and Frisch et al. [1992] and East Pacific Rise MORB (open squares) from $13^{\circ} \mathrm{S}$ to $5^{\circ} \mathrm{N}$ [Langmuir, 1988] .

tholeiitic basalts. This is consistent with a model described by Wildberg [1987], in which the plagiogranites are derived by a two-stage process of fractional crystallization and later filter pressing of a tholeiitic magma. The latter process leaves a residual $\mathrm{Fe}$-rich diabase/gabbro, such as samples NC93-7 and NC93-15.

\section{Comparison to Mid-Ocean Ridge Basalts}

The Nicoya Peninsula rocks are compared to mid-ocean ridge basalt (MORB) glasses from the East Pacific Rise from $13^{\circ} \mathrm{S}$ to $5^{\circ} \mathrm{N}$ [Langmuir, 1988] in Figure 3. The MORB data show relatively coherent trends for all elements; these trends are distinct from the Nicoya suite for most elements. Unlike the Nicoya rocks, the MORB data show an inflection in $\mathrm{CaO}$ and $\mathrm{Sc}$ between $6 \%$ and $8 \% \mathrm{MgO}$, indicating the appearance of clinopyroxene on the liquidus at that time and thus lowpressure fractionation. As discussed previously, clinopyroxene in the Nicoya suite appears to have been part of the fractionating mineral assemblage from at least $\sim 9 \%$ MgO. Because the primary effect of high-pressure fractional crystallization is to increase the temperature at which clinopyroxene appears on the liquidus [e.g., Bender et al., 1978; Grove et al., 1992; Langmuir et al., 1992], fractional crystallization of the Nicoya magmas appear to have occurred at pressures significantly greater than that for MORB.

To examine whether the differences between the MORB and 


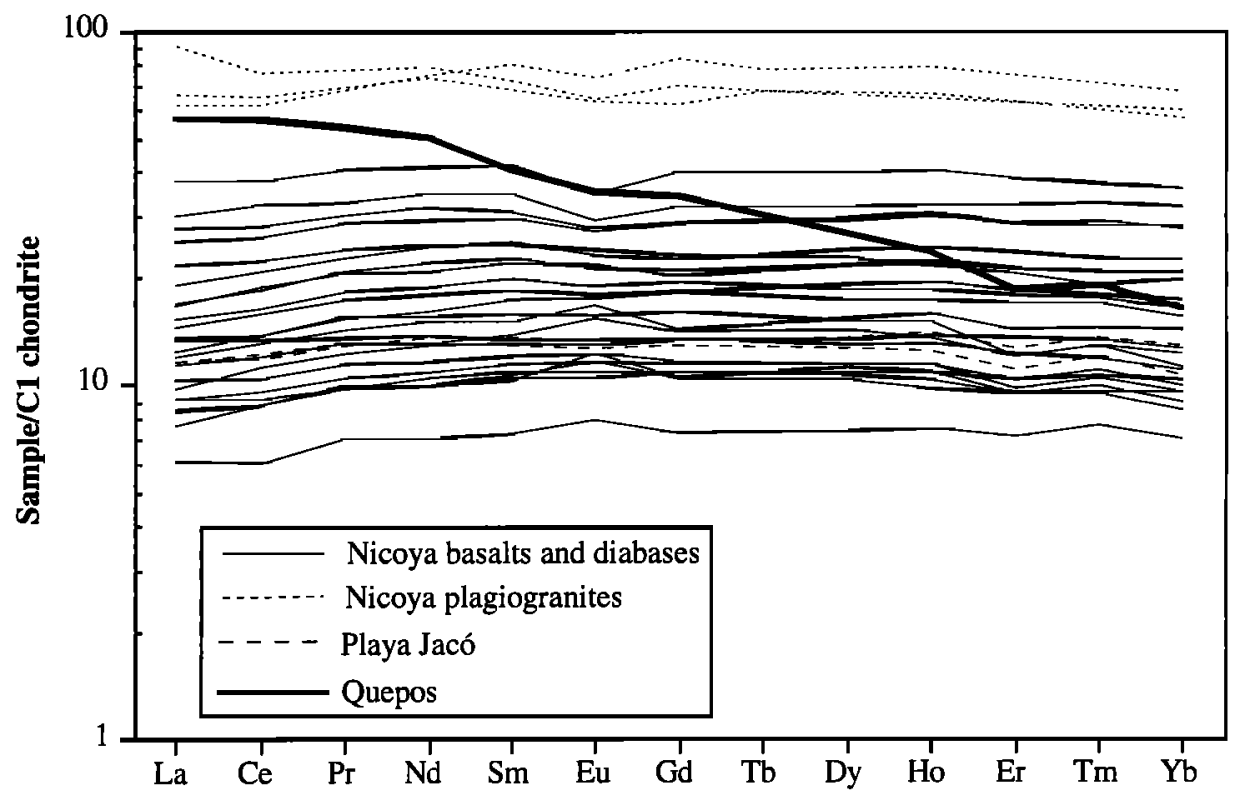

Figure 4. $\mathrm{C} 1$ chondrite-normalized rare earth element diagrams. Basalt and diabase data are from this paper and Sinton [1996]. Plagiogranite data are from Wildberg [1984]. Chondrite values are from McDonough and Sun [1995].

Nicoya magmas are a result of differences in the depth of fractional crystallization (from parental melts of similar major element composition) or of differences in parental melt composition, the two data sets are compared at $9 \% \mathrm{MgO}$. Both data sets have comparable $\mathrm{CaO}$ and $\mathrm{FeO}$, but $\mathrm{Al}_{2} \mathrm{O}_{3}$, which behaves incompatibly and is depleted from the mantle during partial melting [e.g., Forsyth, 1992], is higher in the MORB magmas. Other incompatible elements in the Nicoya suite, such as $\mathrm{TiO}_{2}, \mathrm{Zr}$, and $\mathrm{Y}$, are also slightly to significantly lower than in the MORB suite at $9 \% \mathrm{MgO}$ (Figure 3). These differences cannot be attributed to differences in the fractionating mineral assemblage. Rather, they must reflect a depletion of the Nicoya parental magmas relative to MORB parental magmas. Such a depletion could be caused by higher degrees of partial melting of the mantle.

\section{Rare Earth Elements}

Figure 4 shows the chondrite-normalized rare earth element analyses. All show relatively flat, parallel patterns, consistent with the Nicoya Peninsula rocks belonging to a single, cogenetic suite. All of the Nicoya rocks (including the matrix of the NC93-100 cumulate gabbro) have slightly light rare earth element (LREE) -depleted to slightly LREE-enriched chondrite-normalized REE patterns $\left(\mathrm{La} / \mathrm{Yb}_{\mathrm{n}}=0.77-1.21\right.$, $\mathrm{Ce} / \mathrm{Yb}_{n}=0.85-1.23$ ) with the absolute abundances of the REE increasing with decreasing $\mathrm{MgO}$. The two analyzed Jacó rocks also have relatively flat REE patterns $\left(\mathrm{La} / \mathrm{Yb}_{n}=0.90-1.08\right)$ which, along with the variation diagrams, suggests that they and the Nicoya Peninsula rocks were derived from similar parental magmas. The flat patterns are different from the LREE-depleted patterns displayed by most normal MORB. The Quepos basalt has a LREE-enriched pattern $\left(\mathrm{La} / \mathrm{Yb}_{n}=\right.$ 3.51). This observation and the differences in the variation diagrams and the younger age demonstrates that the Quepos rocks were derived from different parental magmas than the Nicoya and Jacó rocks.
Summarizing the major and trace element results, the Nicoya Peninsula rocks appear to be related by fractional crystallization from similar parental melts. The Jacó basalts are compositionally similar to the Nicoya rocks while the Quepos basalts are distinct as well as significantly younger. The Nicoya rocks are compositionally distinct from MORB lavas in terms of some major and trace elements. These differences may be partly attributed to a difference in the first appearance of clinopyroxene on the liquidus, possibly due to a difference in the pressure at which crystallization occurred, as well as differences in the degree of partial melting of the source mantle. The flat REE patterns of the Nicoya rocks indicate a source that less previous melting than the depleted upper mantle that is the source for normal MORB, and this is confirmed by the isotopic analyses.

\section{Sr-Nd-Pb Isotopic Ratios}

Six of the freshest Nicoya Peninsula samples as well as two Jacó basalts and one Quepos basalt were analyzed for $\mathrm{Sr}, \mathrm{Nd}$, and $\mathrm{Pb}$ isotopes, and the data are presented in Table 4. Both measured and age-corrected initial ratios are reported. $\mathrm{Sr}, \mathrm{Nd}$, and $\mathrm{Pb}$ isotopic ratios were determined by $\mathrm{M}$. Gorring at the Department of Geological Sciences, Cornell University, using a V.G. Sector 54 mass spectrometer [White and Patchett, 1984; White and Dupré , 1986]. Approximately $500 \mathrm{mg}$ aliquots of rock were leached for 2 hours in $6 \mathrm{~N} \mathrm{HCl}$ prior to dissolution. A separate aliquot of NC93-20 was not leached for comparison. The leached and unleached aliquots of sample NC93-20 did not give significantly different results (Table 4). Replicate isotopic analyses for $\mathrm{Sr}$ and $\mathrm{Pb}$ ratios of some of the samples were performed on separate sample dissolutions and show excellent reproducibility (Table 4).

The ${ }^{87} \mathrm{Sr} /{ }^{86} \mathrm{Sr}$ ratios show considerable scatter, while the ${ }^{143} \mathrm{Nd} /{ }^{144} \mathrm{Nd}$ ratios are relatively constant for all of the Costa Rica samples (Figure 5). It is possible that the original $\mathrm{Sr}$ isotopic signature of the rocks has been skewed to more 
Table 4. Sr, Nd, and Pb Isotopic Analyses for Basaltic Rocks from the Nicoya Complex, Costa Rica

\begin{tabular}{|c|c|c|c|c|c|c|c|c|c|c|c|}
\hline Sample & $\frac{{ }^{87} \mathrm{Sr}}{{ }^{86} \mathrm{Sr}}$ & $\frac{{ }^{87} \mathrm{Sr}}{{ }^{86} \mathrm{Sr}_{1}}$ & $\frac{{ }^{143} \mathrm{Nd}}{{ }^{144} \mathrm{Nd}}$ & $\frac{{ }^{143} \mathrm{Nd}}{{ }^{144} \mathrm{Nd}} i$ & $\mathbf{E N d}_{i}$ & $\frac{{ }^{206} \mathrm{~Pb}}{{ }^{204} \mathrm{~Pb}}$ & $\frac{{ }^{206} \mathrm{~Pb}}{{ }^{204} \mathrm{~Pb}}$ & $\frac{{ }^{207} \mathrm{~Pb}}{{ }^{204} \mathrm{~Pb}_{m}}$ & $\frac{{ }^{207} \mathrm{~Pb}}{{ }^{204} \mathrm{~Pb}_{i}}$ & $\frac{{ }^{208} \mathrm{~Pb}}{{ }^{204} \mathrm{~Pb}}$ & $\frac{{ }^{208} \mathrm{~Pb}}{{ }^{204} \mathrm{~Pb}}$ \\
\hline $\mathrm{NC} 93-20 \mathrm{u}$ & 0.70346 & 0.70345 & --- & --- &.- & 19.23 & 19.16 & 15.56 & 15.56 & 38.87 & 38.81 \\
\hline NC93-20 & 0.70341 & 0.70340 & 0.512967 & 0.512843 & 6.26 & 19.28 & 19.21 & 15.59 & 15.58 & 38.97 & 38.90 \\
\hline NC93-18 & 0.70393 & 0.70392 & 0.512990 & 0.512863 & 6.65 & 19.28 & 19.02 & 15.58 & 15.57 & 38.93 & 38.71 \\
\hline NC93-34 & 0.70450 & 0.70442 & 0.512977 & 0.512853 & 6.45 & 19.62 & 19.12 & 15.63 & 15.61 & 39.39 & 38.75 \\
\hline NC93-13 & 0.70329 & 0.70326 & 0.512981 & 0.512860 & 6.59 & 19.34 & 19.15 & 15.63 & 15.62 & 39.14 & 38.84 \\
\hline NC93-11 & 0.70316 & 0.70314 & 0.513014 & 0.512886 & 7.10 & 19.68 & 19.22 & 15.60 & 15.58 & 39.47 & 38.89 \\
\hline NC93-3 & 0.70361 & 0.70360 & 0.512985 & 0.512863 & 6.65 & 19.33 & 19.20 & 15.60 & 15.60 & 39.08 & 38.81 \\
\hline NC93-3R & 0.70346 & 0.70344 & --- & --- & --- & 19.26 & 19.13 & 15.57 & 15.56 & 38.91 & 38.64 \\
\hline JC93-1 & 0.70347 & 0.70345 & 0.512955 & 0.512848 & 6.36 & 19.37 & 19.21 & 15.58 & 15.57 & 39.04 & 38.84 \\
\hline JC93-1R & 0.70344 & 0.70342 & ---- & -- & --- & 19.34 & 19.19 & 15.56 & 15.55 & 38.98 & 38.78 \\
\hline JC93-3 & 0.70313 & 0.70310 & 0.512987 & 0.512878 & 6.94 & 19.38 & 19.06 & 15.60 & 15.58 & 39.06 & 38.69 \\
\hline JC93-3R & --- & --- & --- & -- & -- & 19.40 & 19.09 & 15.60 & 15.59 & 39.12 & 38.75 \\
\hline QP93-1 & 0.70460 & 0.70450 & 0.512916 & 0.512850 & 6.40 & 19.43 & 19.21 & 15.61 & 15.60 & 39.06 & 38.77 \\
\hline QP93-1R & $\cdots$ & --- & 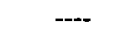 & --- & --- & 19.40 & 19.18 & 15.58 & 15.57 & 38.94 & 38.66 \\
\hline
\end{tabular}

All samples were acid leached prior to dissolution except NC93-20u. The " $m$ " subscript denotes measured values; the " $i$ " subscript denotes values age corrected using concentrations from inductively coupled plasma mass spectrometer analyses and $90 \mathrm{Ma}$ for the Nicoya rocks, $84 \mathrm{Ma}$ for the Jaco rocks, and $64 \mathrm{Ma}$ for the Quepos sample. Replicates are denoted with " $R$ " and are complete replicates, that is, they are analyses of separate rock sample aliquots.

radiogenic values by $\mathrm{Sr}$ addition, considering that the most altered of the analyzed samples (QP93-1) has the highest ${ }^{87} \mathrm{Sr} /{ }^{86} \mathrm{Sr}$. However, this relationship is not clear, given that sample NC93-34 from the Nicoya Peninsula is virtually unaltered and its high ${ }^{87} \mathrm{Sr} /{ }^{86} \mathrm{Sr}$ ratio cannot be readily explained by seafloor alteration. This sample was taken near a large intruded body of radiolarian chert, so it is possible that the $\mathrm{Sr}$ isotopic signature has been increased by the assimilation of pelagic sediments. Considering these possible contamination effects, $\mathrm{Sr}$ isotopes cannot be used as reliable indicators of mantle sources in this suite.

The contamination from pelagic sediments that is evident from the $\mathrm{Sr}$ isotopes is not apparent in the $\mathrm{Nd}$ and $\mathrm{Pb}$ isotopes (nor, for that matter, in the trace element data). This is not unexpected for $\mathrm{Nd}$, as $\mathrm{Nd}$ concentrations in seawater and pelagic sediments are very low. The range of initial ${ }^{143} \mathrm{Nd} /{ }^{144} \mathrm{Nd}$ ratios for the samples is small $(0.51285$ 0.51289 ). The $\mathrm{Pb}$ isotopic ratios also show a restricted range and show no evidence of a mixing trend toward pelagic sediment $\mathrm{Pb}$ isotopic compositions [Doe, 1970] (Figure 5).

On ${ }^{206} \mathrm{~Pb} /{ }^{204} \mathrm{~Pb}$ vs. ${ }^{207} \mathrm{~Pb} /{ }^{204} \mathrm{~Pb}$ and ${ }^{206} \mathrm{~Pb} /{ }^{204} \mathrm{~Pb}$ vs. ${ }^{208} \mathrm{~Pb} /{ }^{204} \mathrm{~Pb}$ diagrams, the age-corrected Costa Rica rocks plot in a group that is more radiogenic than present day East Pacific Rise basalts. Considering the analytical error, the $\mathrm{Pb}$ and $\mathrm{Nd}$ isotopic ratios of all of the analyzed samples are not appreciably different, although NC93-11 and NC93-34 have ${ }^{206} \mathrm{~Pb} /{ }^{204} \mathrm{~Pb}$ and ${ }^{208} \mathrm{~Pb} /{ }^{204} \mathrm{~Pb}$ ratios considerably more radiogenic than the others. Together, the $\mathrm{Nd}$ and $\mathrm{Pb}$ isotopic data show that the mantle sources for the Nicoya Peninsula, Jaco, and Quepos magmas were similar. These sources are enriched relative to the depleted, upper mantle source for normal MORB from the East Pacific Rise.

\section{Discussion}

\section{A Single Magmatic Suite}

Ideally, the interpretation of the petrogenetic history of a suite of igneous rocks should be based on the integrated observations from fieldwork, petrography, geochronology, and chemistry. In western Costa Rica, individual flow units are virtually impossible to identify and stratigraphic relationships between the different outcrops are unconstrained, so we must rely more on the geochemical and age data in interpreting the magmatic history of the suite. We have made a case that the rocks of the Nicoya Peninsula are part of a single suite of variably differentiated rocks derived from similar parental magmas. On the basis of the ${ }^{40} \mathrm{Ar}-{ }^{39} \mathrm{Ar}$ studies, the magmas crystallized at 88 to $90 \mathrm{Ma}$ while some intrusive magmatic activity occurred at $84 \mathrm{Ma}$. The previous designations of a lower unit of normal mid-ocean ridge generated crust and an upper unit partially made of oceanic plateau lavas [Schmidt-Effing, 1979; Kuijpers, 1980; Bourgois et al., 1984; Gursky et al., 1984; Wildberg, 1984; Frisch et al., 1992] appear to be untenable.

The primitive arc series proposed by Wildberg [1984] and Frisch et al. [1992] was based on the observation that some rocks have relatively low concentrations of certain high field strength elements (HFSE) (e.g., $\mathrm{Zr}$ and $\mathrm{Ti}$ ) and some have high ${ }^{87} \mathrm{Sr} /{ }^{86} \mathrm{Sr}$ ratios, which can be a characteristic of arc lavas. However, these studies did not note that the low HFSE lavas also have relatively high $\mathrm{MgO}$ contents and the depletion of HFSE (as well as other incompatible elements) is an effect of dilution (that is, less fractionated samples have lowest absolute incompatible element concentrations). As we have 

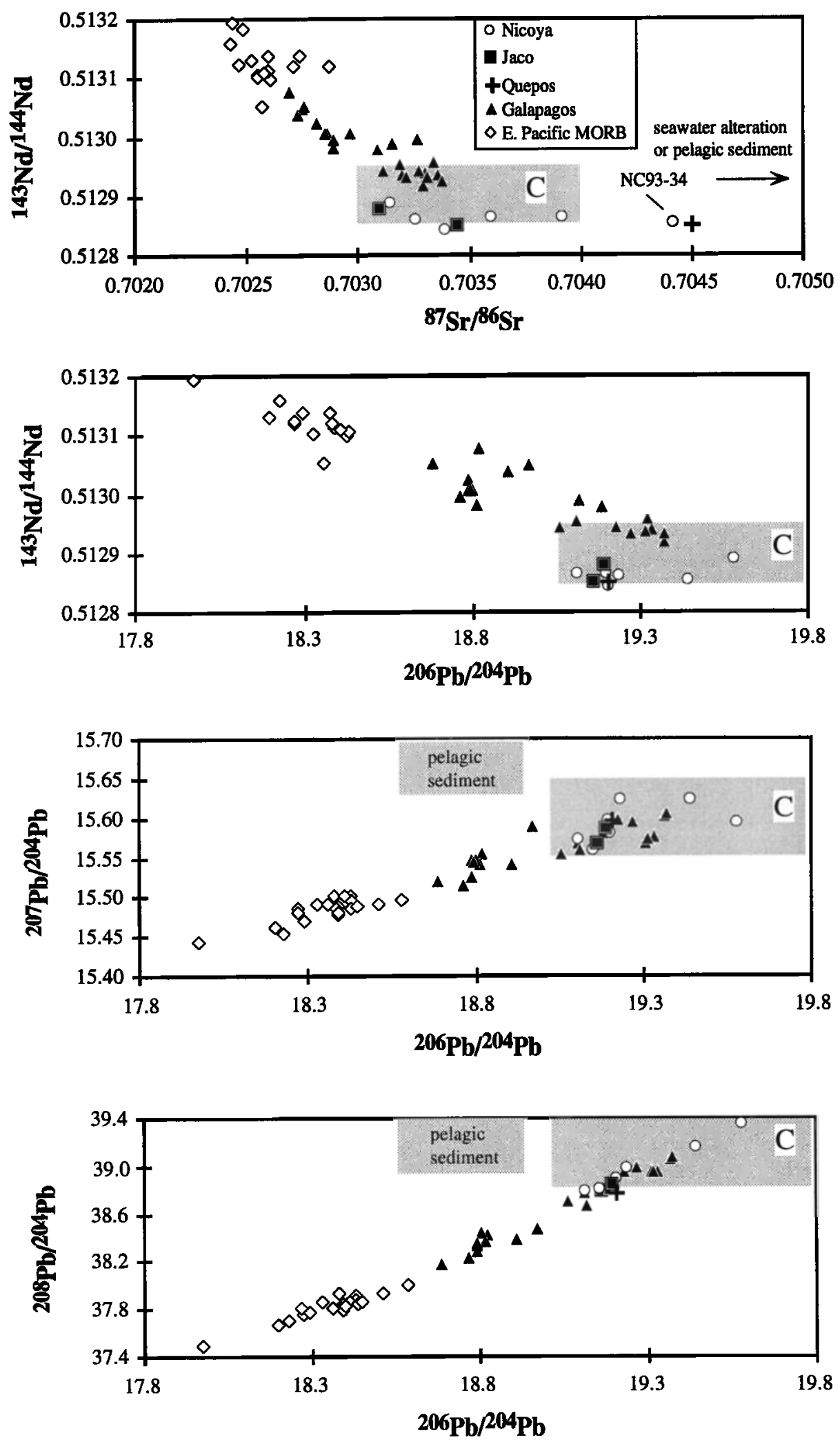

Figure 5. $\mathrm{Sr}, \mathrm{Nd}$, and $\mathrm{Pb}$ isotopic ratio correlation plots. Typical analytical uncertainties are indicated by the size of the symbols. East Pacific MORB data are from White et al. [1987] and Prinzhofer et al. [1989]. Pelagic sediment values from Doe [1970]. C is the common plume composition reported by Hanan and Graham [1996]. NC93-34 is an unaltered diabase that may have incorporated radiogenic Sr from pelagic sediment contamination. 
shown, ${ }^{87} \mathrm{Sr} /{ }^{86} \mathrm{Sr}$ ratios cannot be reliably used as a geochemical discriminant with the Nicoya lavas and therefore conclusions based on these are suspect.

We cannot definitively state that all of the pre-Tertiary rocks of the Nicoya Peninsula are from the same Late Cretaceous suite. The radiolarian chert must have been deposited on oceanic crust that is at least of Jurassic age (H.-J. Gursky, personal communication, 1994). What we have shown is that the rocks that have thus far been analyzed are not Jurassic MORB. We consider that the blocks of radiolarian chert were either entrained by massive submarine lava flows or heavily penetrated by sills and dikes. Implicit in this conclusion is that the Late Cretaceous magmas erupted in an intraplate setting through preexisting oceanic crust. Some of the older oceanic igneous crust over which the radiolarian chert was deposited may be found to be commingled with the plateau lavas described here by continued sampling and analysis.

Eruption through preexisting lithosphere provides a ready model to explain the greater depth of crystal fractionation, compared to that at which normal MORB magmas are pooled. Because the lithospheric thicknesses at mid-ocean ridges are negligible, melts pool at shallow depths (1-2 km below seafloor). In contrast, the parental melts of the Nicoya suite may have pooled beneath the pre-existing, perhaps $20-50$ m.y. old oceanic lithosphere, resulting in fractional crystallization at depths exceeding 20-30 km below seafloor. However, we cannot discount the possibility that the relatively early onset of clinopyroxene crystallization was due to a greater diopside component in the Nicoya parental magmas relative to those of normal MORB.

\section{Relationship of Jacó and Quepos Lavas to the Nicoya Peninsula Suite}

In the field, the Jacó rocks are identical to the Nicoya Peninsula suite; massive, faulted, and fractured basalt flows; but the one radiometric age indicates that magmatism occurred at $84 \mathrm{Ma}$. It is not clear at this point whether volcanism in this location was continuous from 88 to $84 \mathrm{Ma}$, but it is possible that the Jacó basalt and $84 \mathrm{Ma}$ Nicoya intrusives are related to a common magmatic phase, based on their similarity in age and composition. The compositional similarity between all of the Nicoya and Jacó rocks indicates that there was no change in mantle source or conditions between 90 and $84 \mathrm{Ma}$.

The Quepos basalts are considerably younger than the Nicoya and Jacó suite and have major and trace element compositions that reflect smaller degrees and perhaps deeper partial melting. It is possible that the Quepos lavas represent an accreted seamount (M. Meschede, personal communication, 1994) that originated on the subducting Farallon (now Cocos) plate. As indicated by the isotopic ratios, the Quepos lavas appear to have been derived from a mantle source similar to that of the Nicoya and Jacó rocks. If this is the case, then there must have been a long-term, active thermal anomaly in the area. An attractive candidate is the Galapagos hotspot (see following section). It is likely that the Quepos lavas were part of an older, now subducted extension of the aseismic Cocos Ridge, which was produced by the northeast motion of the Farallon plate over the Galapagos hotspot [Hey et al. , $1977]$.

\section{Relationship to the Caribbean Oceanic Plateau}

It has been previously suggested that a portion of the Nicoya Complex is related to the thick Cretaceous Caribbean crust [e.g., Wildberg, 1984], which is considered to be the remnant of an oceanic plateau produced by initial, massive volcanism over the Galapagos plume [Duncan and Hargraves, 1984]. This is supported by the fact that the $\sim 90 \mathrm{Ma}$ ages of the Nicoya Peninsula basalts fall within the narrow range of radiometric ages from basaltic rocks in Haiti, Curaçao, Colombia, and Gorgona Island [Sinton, 1996]. The relatively flat REE patterns and $\mathrm{Nd}$ and $\mathrm{Pb}$ isotopic ratios of the Nicoya and Jacó rocks are also similar to some of the Caribbean plateau lavas [Sinton, 1996]. Thus we conclude that the Nicoya Peninsula rocks are one of many pieces of the Caribbean plateau exposed by collisional tectonics around the margins of the Caribbean plate.

$\mathrm{Sr}, \mathrm{Nd}$, and $\mathrm{Pb}$ isotopic ratios are excellent tracers of mantle source composition because they remain unchanged during partial melting and fractional crystallization. Differences in these ratios among magmas can be ascribed to the mixing of magmas or mantle sources. The $\mathrm{Nd}$ and $\mathrm{Pb}$ isotopic ratios indicate that the Nicoya rocks and probably the Jacó and Quepos basalts were derived from similar mantle sources which are more enriched than the depleted upper mantle from which normal MORB are derived. The isotopic ratios plot within the field of present day Galapagos lavas [White et al. 1993], consistent with derivation from the Galapagos mantle plume. In terms of mantle end-members described by isotopic composition [e.g., Zindler and Hart , 1986], the source for the Costa Rica rocks could be interpreted as a mixture between depleted upper mantle (DMM) and an enriched (HIMU) source. Alternatively, the data plot near or within the general range of a common mantle source (FOZO, [Hart et al., 1992]; PHEM, [Farley et al., 1992]; C, [Hanan and Graham, 1996]) (Figure 5). According to Hanan and Graham [1996], this common mantle source may be located in the transition zone between the upper and lower mantle or at the core-mantle boundary.

\section{Melting Conditions}

The mantle melting conditions that produced the Nicoya lavas can be constrained using the compositional data. However, most mantle melting studies using geochemistry have focused on mid-ocean ridge environments [e.g., Klein and Langmuir, 1987; Johnson et al. , 1990] and not on oceanic plateaus. Partial melting of the mantle below midocean ridges appears to be controlled by polybaric melting of a column of mantle with pooling of discrete melt packets from different depths [e.g., Klein and Langmuir, 1987; Johnson et al. , 1990; Grove et al. , 1992]. It is likely that a similar process, but operating on a larger scale, produced the Nicoya lavas and oceanic plateaus in general. Oceanic plateaus, which have characteristics indicative of rapidly constructed submarine flood basalt provinces, are probably produced by relatively high degrees of partial melting [Storey et al. , 1991; Mahoney et al. , 1993], and so the general melting regime was significantly larger and more ephemeral than that of mid-ocean ridge melting. The depletion of some incompatible elements in the Nicoya rocks relative to MORB cannot be attributed to a more depleted mantle source, given that the REE and isotopic data indicate a relatively undepleted 
mantle source. Therefore the depletions are best explained by higher degrees of partial melting of the mantle.

Higher degrees of melting are also indicated by the high$\mathrm{MgO}$ lavas that are found in the Santa Elena Peninsula (low-Ti basalt of Wildberg [1984]) and to the north of Playa Jacó/Herradura [Alvarado et al., 1997]. An ${ }^{40} \mathrm{Ar}-{ }^{39} \mathrm{~A} \mathrm{r}$ radiometric age of plagioclase from a lava in the latter of these sections is $89.7 \pm 1.4 \mathrm{Ma}$ [Alvarado et al., 1997], which indicates anomalously high thermal conditions in the mantle at this time.

Sinton [1996] used batch melting equations to show that a potential primary magma for the Nicoya basalt suite could be produced by $30 \%$ melting of a mixed depleted and primitive mantle. Although it is possible or even likely that fractional or near-fractional melting occurred during formation of the primary magmas, if the fractional melts accumulated before eruption, then the aggregate melt compositions would have been identical to batch melting [Shaw , 1970; Johnson et al. , 1990]. Such a high degree of melting was also reported by Mahoney et al. [1993] for the Ontong Java oceanic plateau lavas.

The pattern of QP93-1 indicates that either the mantle source was enriched in LREE or that garnet was residual in the source mantle or both. Sinton [1996] showed that a calculated primary magma for this sample could have been generated by mixing a $5 \%$ melt of a garnet-bearing mantle with a $10 \%$ melt of the spinel-bearing mantle.

\section{Conclusions}

Our combined data indicate that the mafic oceanic rocks of the Nicoya Peninsula belong to a single magmatic suite, the vast majority of which formed within a short period at 88-90 $\mathrm{Ma}$. The data are not consistent with the division of the Nicoya Peninsula rocks into separate suites. Two intrusive rocks (a gabbro and a plagiogranite) are slightly younger at $84 \mathrm{Ma}$, suggesting intrusive activity occurred after the initial volcanic eruptions. We cannot discount the possibility that fragments of Jurassic to Early Cretaceous oceanic crust exist in the Nicoya Peninsula and that these have not been identified. The coherent trends in the variation diagrams, the similarity in the REE diagrams, and the similarity in Nd and $\mathrm{Pb}$ isotopes provide strong evidence that the rocks collected thus far from the Nicoya Peninsula are related to the same event. This event is most likely the formation of the Caribbean oceanic plateau, based on similarities in age and compositions to exposed sections of the plateau around the Caribbean plate margins [Donnelly et al., 1990; Sinton, 1996]. The Playa Jacó/Herradura basalts are slightly younger (84 Ma) than the Nicoya Peninsula basalts and diabases but are compositionally identical. The Quepos basalts are significantly younger ( $64 \mathrm{Ma}$ ) and formed by smaller degrees of partial melting of a mantle source similar to the one from which the Nicoya magmas were derived. All of the obducted mafic material in western Costa Rica rocks could be products of the Galapagos mantle plume.

Acknowledgments. We would like to thank D. Christie, D. Graham, and A. Grunder for their helpful comments and input and M. Gorring for doing the isotopic analyses. We are indebted to K. Cameron, T.W. Donnelly, and D. Elthon for helpful reviews. M. Meschede and H.-J. Gursky provided valuable advice during the planning stages of this project. This research has been supported by the National Science Foundation.

\section{References}

Alvarado, G. E., S. Kussmaul, S. Chiesa, P.-Y. Gillot, H. Appel, G. Wörner, and C. Rundle, Resumen cronoestratigráfico de las rocas ígneas de Costa Rica basado en dataciones radiométricas, $J$. South Am. Earth Sci., 6, 151-168, 1993.

Alvarado, G. E., P. Denyer, and C. W. Sinton, The 89 Ma Tortugal komatiitic suite, Costa Rica: Implications for a common geological origin in the Caribbean and Eastern Pacific region from a mantle plume, Geology, in press, 1997.

Baumgartner, P. O., C. R. Mora, J. Butterlin, J. Sigal, G. Glaçon, J. Azéma, and J. Bourgois, Sedimentación y paleografía del Cretácico y Cenozoico del litoral pacífico de Costa Rica, Rev. Geol. Am. Cent, , 1, 57-136, 1984.

Bender, J. F., F. N. Hodges, and A. E. Bence, Petrogenesis of basalts from the project FAMOUS area: Experimental study from 0 to 15 kbars, Earth Planet. Sci. Lett., 41, 277-302, 1978.

Bourgois, J., J. Azema, P. O. Baumgartner, J. Tournon, A. Desmet, and J. Auboin, The geologic history of the Caribbean-Cocos plate boundary with special reference to the Nicoya ophiolite complex (Costa Rica) and DSDP results (Legs 67 and 84 off Guatemala): A synthesis, Tectonophysics, 108, 1-32, 1984.

Dalrymple, G. B., D. A. Clague, T. L. Vallier, and H. W. Menard, ${ }^{40} \mathrm{Ar}-$ ${ }^{39} \mathrm{Ar}$ age, petrology, and tectonic significance of some seamounts in the Gulf of Alaska, in Seamounts, Islands, and Atolls, Geophys. Monogr. Ser., vol. 43, edited by B. H. Keating, P. Fryer, R. Bat1za and G. W. Boehlert, pp. 297-315, AGU, Washington, D.C., 1988.

Deer, W. A., R. A. Howie, and J. Zussman,An Introduction to the Rock Forming Minerals, 696 pp., Longman, White Plains, N.Y., 1992.

Dengo, G., Tectonic igneous sequence in Costa Rica, in Petrologic Studies: A Volume to Honor A.F. Buddington, edited by A. E. J. Engel, H. L. James and B. F. Leonard, pp. 133-161, Geol. Soc. Am., Boulder, Colo., 1962.

Denyer, P., and O. Arias, Geologia del norte de la Peninsula de Nicoya, Costa Rica, Rev. Geol. Am. Cent., 16, 69-84, 1993.

Diebold, J. B., P. L. Stoffa, P. Buhl, and M. Truchan, Venezuela basin crustal structure, J. Geophys. Res., 86, 7901-7923, 1981.

Doe, B. R., Lead Isotopes, 137 pp., Springer-Verlag, N.Y., 1970.

Donnelly, T. W., The Caribbean Creataceous basalt association: A vast igneous province that includes the Nicoya Complex of Costa Rica, Profil, vol. 7, pp. 17-45, Univ. of Stuttgart, Stuttgart, Germany, 1994.

Donnelly, T. W., et al., History and tectonic setting of Caribbean magmatism, in The Caribbean Region, vol. $\mathrm{H}$, edited by G. Dengo and J. E. Case, pp. 339-374, Geo. Soc. Am., Boulder, Colo., 1990.

Duncan, R. A., and R. B. Hargraves, Plate tectonic evolution of the Caribbean region in the mantle reference frame, in The CaribbeanSouth American Plate Boundary and Regional Tectonics, edited by W. E. Bonini, R. B. Hargraves and R. Shagam, pp. 81-93, Mem. Geo. Soc. Am., 16, 81-93, Boulder, Colo., 1984.

Duncan, R. A., and R. B. Hargraves, ${ }^{40} \mathrm{Ar} /{ }^{39} \mathrm{Ar}$ geochronology of basement rocks from the Mascarene Plateau, Chagos Bank, and Maldives Ridge, Proceedings of the Ocean Drilling Program, Scientific Results, 115, edited by R. A. Duncan, J. Backman and L. C. Peterson, pp. 43-52, Ocean Drill. Program, College Station, Tex., 1990.

Duncan, R. A., and L. G. Hogan, Radiometric dating of young MORB using the ${ }^{40} \mathrm{Ar}-{ }^{39} \mathrm{Ar}$ incremental heating method, Geophys. Res. Lett., 21, 1927-1930, 1994.

Escalante, G., The geology of southern Central America and western Colombia, in The Caribbean Region, vol. H, edited by G. Dengo and J. E. Case, pp. 201-230, Geol. Soc. Am., Boulder, Colo., 1990.

Farley, K. A., J. H. Natland, and H. Craig, Binary mixing of enriched and undegassed (primitive?) mantle components ( $\mathrm{He}, \mathrm{Sr}, \mathrm{Nd}, \mathrm{Pb}$ ) in Samoan lavas, Earth Planet Sci. Lett., 111, 183-192, 1992.

Forsyth, D. W., Geophysical constraints on mantle flow and melt generation beneath mid-ocean ridges, in Mantle Flow and Melt Generation at Mid-Ocean Ridges,, Geophys. Monogr. Ser., vol. 71, edited by J. Phipps Morgan, D. K. Blackman and J. M. Sinton, pp. 165, AGU, Washington, D.C., 1992.

Frisch, W., M. Meschede, and M. Sick, Origin of the Central American ophiolites: Evidence from paleomagnetic results, Geol. Soc. Am. Bull., 104, 1301-1314, 1992.

Galli-Olivier, C., Ophiolite and island arc volcanism in Costa Rica, Geol. Soc. Am. Bull., 90, 444-452, 1979.

Gradstein, F. M., F. P. Agterberg, J. G Ogg, J. Hardenbol, P. van Veer, 
J. Thierry, and Z. Huang, A Mesozoic timescale, J. Geophys. Res., 99, 24,051-24,074, 1994.

Grove, T. L., R. J. Kinzler, and W. B. Bryan, Fractionation of midocean ridge basalt (MORB), in Mantle Flow and Melt Generation at Mid-Ocean Ridges, Geophys. Monogr. Ser., vol. 71, edited by J. Phipps Morgan, D. K. Blackman and J. M. Sinton, pp. 281-310, AGU, Washington, D.C., 1992.

Gursky, H.-J., M. Gursky, R. Schmidt-Effing, and H. Wildberg, Karten zur Geologie von Nordwest Costa Rica (Mittelamerika) mit Erläuten, Geol. Palaontol., 18, 173-182, 1984.

Hanan, B. B., and D. W. Graham, Lead and helium isotopic evidence from oceanic basalts for a common deep source of mantle plumes, Science, 272, 991-995, 1996.

Hart, S. R., E. H. Hauri, L. A. Oschmann, and J. A. Whitehead, Mantle plume entrainment: Isotopic evidence, Science, 256, 517-519, 1992.

Hey, R., G. L. Johnson and A. Lowrie, Recent plate motions in the Galápagos aren, Geol. Soc. Am. Bull., 88, 1385-1403, 1977.

Hooper, P. R., D. M. Johnson, and R. M. Conrey, Major and trace element analysis of rocks and minerals by $\mathrm{X}$-ray spectrometry, Open File Report, Geol. Dept., Wash. State Univ., Pullman, Wash., 1993.

Hurford, A. J., and K. Hammerschmidt, ${ }^{40} \mathrm{Ar} /{ }^{39} \mathrm{Ar}$ and $\mathrm{K}$-Ar dating of the Bishop and Fish Canyon Tuffs: Calibration ages for fission-track dating standards, Chem. Geol., 58, 23-32, 1985.

Johnson, K. T., H. J. B. Dick and N. Shimizu, Melting in the oceanic upper mantle: An ion microprobe study of diopsides in abyssal peridotites, J. Geophys. Res., 95, 2661-2678, 1990.

Klein, E. M., and C. H. Langmuir, Global correlations of ocean basalt chemistry with axial depth and crustal thickness, J. Geophys. Res., 92, 8089-8115, 1987.

Kuijpers, E. P., The geologic history of the Nicoya Ophiolite Complex, Costa Rica and its geotectonic significance, Tectonophysics, 68 , 233-255, 1980.

Langmuir, C., East Pacific Rise Data Synthesis (petrology database), vols. 1 and 2, Joint Oceanogr. Inst., Washington, D.C., 1988.

Langmuir, C. H., E. M. Klein, and T. Plank, Petrological systematics of mid-ocean ridge basalts: constraints on melt generation beneath ocean ridges, in Mantle Flow and Melt Generation at Mid-Ocean Ridges., Geophys. Monogr. Ser., vol. 71, edited by J. Phipps Morgan, D. K. Blackman and J. M. Sinton, pp. 183-280, AGU, Washington, D.C., 1992.

Mahoney, J. J., M. Storey, R. A. Duncan, K. J. Spencer, and M. Pringle, Geochemistry and age of the Ontong Java Plateau, in The Mesozoic Pacific Geology, Tectonics, and Volcanism, Geophys. Monogr. Ser., vol. 77, edited by M. Pringle, et al., pp 233-261, AGU, Washington, D.C., 1993.

McDonough, W. F., and S.-s. Sun, The composition of the Earth, Chem. Geol., 120, 223-253, 1995.

Pringle, M., Age progressive volcanism in the Musicians Seamounts: A test of the hotspot hypothesis for the Late Cretaceous Pacific, in The Mesozoic Pacific Geology, Tectonics, and Volcanism, Geophys. Monogr. Ser., vol. 77, edited by M. Pringle, et al., pp. 187-215, AGU, Washington, D.C., 1993.
Prinzhofer, A., E. Lewin, and C. J. Allegre, Stochastic melting of the marble cake mantle: Evidence from local study of the East Pacific Rise, Earth Planet Sci. Lett., 92, 189-206, 1989.

Pyle, D. G., D. M. Christie, J. J. Mahoney, and R. A. Duncan, Geochemistry and geochronology of ancient southeast Indian and southwest Pacific seafloor, J. Geophys. Res., 100, 22,261-22,282, 1995.

Schmidt-Effing, R., Alter und genese des Nicoya-Komplexes einer ozeanischen Päleokruste (Oberjura bis Eozän) im südlichen Zentralamerika, Geol. Rundsch., 68, 457-494, 1979.

Shaw, D. M., Trace element fractionation during anatexis, Geochim. Cosmochim. Acta, 34, 237-243, 1970.

Sinton, C. W. 1996. A tale of two large igneous provinces: Geochronological and geochemical studies of the North Atlantic Volcanic Province and the Caribbean Oceanic Plateau, Ph.D. thesis, Oreg. State Univ., Corvallis, 1996.

Storey, M., J. J. Mahoney, L. W. Kroenke, and A. D. Saunders, Are oceanic plateaus site of komatiite formation?, Geology, 19, 376-379, 1991.

White, W. M., and B. Dupré, Sediment subduction and magma genesis in the Lesser Antilles: Isotopic and trace element constraints, $J$. Geophys. Res., 91, 5927-5941, 1986.

White, W. M., and P. J. Patchett, Hf-Nd-Sr and incompatible element abundances in island arcs: implications for magma origins and crustmantle evolution, Earth Planet Sci. Lett., 67, 167-185, 1984.

White, W. M., A. W. Hofmann, and H. Puchelt, Isotope geochemistry of Pacific mid-ocean ridge basalt, Earth Planet Sci. Lett., 92, 4,8814,893, 1987.

White, W. M., A. R. McBirney, and R. A. Duncan, Petrology and geochemistry of the Galapagos Islands: Portrait of a pathological mantle plume, J. Geophys. Res., 98, 19,533-19,563, 1993.

Wildberg, H.,Der Nicoya-Komplex, Costa Rica, Zentralamerika: Magmatisme und Genese polygenetischen Ophiolith-Komplexes, vol. 62, 123 pp., Münsterisches Forsch. Geol. und Paläontol., 1984.

York, D., Least-squares fitting of a straight line with correlated errors, Earth Planet Sci. Lett., 5, 320-324, 1969.

Zindler, A., and S. R. Hart, Chemical geodynamics, Annu. Rev. Eurth Planet. Sci., 14, 493-571, 1986.

P. Denyer, Escuela Centroamericana de Geología, Universidad de Costa Rica, Apdo. 35-2060, San Jose, Costa Rica.

R.A. Duncan, College of Oceanic and Atmospheric Sciences, Oregon State University, Corvallis, OR 97331

C.W. Sinton, Graduate School of Oceanography, University of Rhode Island, South Ferry Road, Narragansett, RI 02882. (email: csinton@gsosun I.gso.uri.edu)

(Received September 3, 1996; revised February 25, 1997; accepted February 26, 1997.) 